\title{
Thinking About the Information Construction of Rural Tourism in the
}

\section{Background of Internet Age}

\author{
Shuyan Lei ${ }^{1}$ \\ ${ }^{1}$ College of Business Administration, Nanchang Institute of Technology, Nanchang 330044, China
}

Keywords: Internet age, rural tourism, information construction

\begin{abstract}
The 21st century is an information-intensive society with economic development. With the information transfer characteristics of convenient communication, it gradually settles each station of society, the information construction of rural tourism in the background of internet age is the new height of tourism information construction of China. Rural tourism information technology is an irreversible trend of the times, part of the development of the times, and the promotion of economic growth. In the background of information construction in rural areas, the rural infrastructure of information technology has made significant progress. Combined with information of infrastructure, rural tourism accelerates development through the establishment of regional platform and demonstration model, etc.
\end{abstract}

\section{Introduction}

Information construction of rural tourism is an inevitable trend of modern social development, and tourism is a comprehensive industry with association height and wide coverage, which is inseparable from the development in collaboration with civil aviation, railway, transportation and other industries, but also from commerce, catering, entertainment and supporting services, and information is the unifying bond of all links inside tourism.

In 90s of last century, computer network technology made rapid development and applications in social marketing, and information technology became the booster of promoting productive development and social progress. Modern tourism information takes full use of network computer to integrate and disseminate information resources to promote tourism to more flourish.

\section{Tourist information meaning and problems in information construction of rural tourism}

Tourist information takes full use of computer and network technology for integration of various information resources of tourism to make it the productive forces of tourism development, an important means of promoting the development of tourism industry and management level. The information age creates the conditions so that all citizens enjoy science and technology development results and development opportunities. Rural tourism information can promote agricultural development, farmers’ income, rural economic and social development.

Tourist information can save time and money of rural tourists. Along with social and economic development, accelerated pace of life, tourists' increasingly rich consumer experience, tourists pay more and more attention on quality requirements, but now the information development situation of rural tourism is not optimistic, and there are the following problems:

(1) Rural tourism problems of information construction

The problem comes from the widespread shortage of rural tourism resources structure, which 
restricts the overall development of rural tourism, rural area is unable to take advantage of its environmental advantages so that environmental resources cannot be used with high quality.

(2) The development of network information technology foundation is weak

There is a wide range of business personnel training, with deficiencies in personnel management of automatic network information, scarce innovative network information management talent, and lack of network information technology training and understanding of the nature of the tourism industry, the network is the reference way to understand the tourism information. The shallow understanding of network information and tourism information itself, the fundamental problems of tourism cannot be solved on information technology development.

(3) The rural tourism quality information exists security issues

As the knowledge of network is becoming increasingly popular, most consumers make online consuming choice. Network information is convenient, but the complexity and development of the network is not as simple as the consumer imagine. Online banking, online payment and online trading related to money, through the inside information of major companies or defrauding consumers' personal information posing as businessmen in the name of the software, by these so-called computer gangster tampering, they may enter the site with impersonation of businesses and consumers so that consumers compromise. Therefore, consumers do not want to believe or access the network.

\section{Development approach and role in information construction of rural tourism}

Tourism is a sensitive industry, which particularly strongly depends on information. As the most active factor in productivity, information technology gradually penetrates and changes modern tourism, and accelerates the development trends of international tourism in many ways. Any countries divorced from travel information development path will fall into information island state. Therefore, to adapt the rapid development of information technology, the opening demands of the market after entering WTO, to provide comprehensive information support and resource sharing, and global tourism are necessary condition for information of tourism industry.

Innovation in information technology, improvements in transport facilities and transport, and supply conditions improvement provides favorable conditions for the individual needs of tourists, people's travel behavior is becoming much more diverse and personalized, therefore, tourism businesses must comprehensively collect, refine and integrate the demand characteristics of various tourism resources and tourists, through appropriate network platform to provide more travel information for rural travelers to save time and money.

Rural tourism mainly relies on well-known sites and attractions, so strengthening the construction of tourist information, passing the related rural information to the majority of tourism travel enthusiasts through the network platform to improve understanding of rural tourism, will be able to attract more tourists. Strengthen rural tourism website building to ensure that the development of rural tourism has excellent tourist information service support to meet the tourist information consumption and improve the market economy personality of tourism.

Network becomes the main tool for villagers to promote its rural culture and tourism, emerging in the information development of rural tourism. Information construction of rural tourism is a long process of development, which requires constant innovation and development to save resources advantages, protect rural natural ecological environment and bring economic benefits for rural tourism. Strengthening the development strategy of rural tourism information and maintaining the unique characteristics of local resources should combine rural area and network information. As leisure patterns, rural tourism is closely related to urban residents, the formation and development 
of the new consumption situation.

The formation of rural information will also be a gradual process. In terms of the initial development, the government should do a good job on market development, use a variety of media, especially the high-impact local news, live network, forums and other sites related to the Travel Channel to carry strong links to promote the formation of rural tourism products port, use the existing network infrastructure to release relevant information of rural tourism product, but also on the overall planning of information construction of rural tourism by the government, make standards, regulate the construction, government support is a necessary condition of information construction of rural tourism. The development of rural tourism will be handed over to the government for information technology audits, through ideologies and politics, economic, cultural improvement, promote natural features and positive attitude of rural villagers and other aspects of assessment, let the information construction and development of rural tourism obtain government approval and recognition.

Government departments need to undertake overall planning for rural tourism information, develop uniform standards, norm construction direction, develop oversight role, establish Work Leading Group in information construction of rural tourism, implement system of labor responsibility division, promote information projects scientifically and effectively.

To break the most basic forms of tourism and let information construction of rural network tourism gain confidence and affirmation of local people and consumer, it will give the information construction of rural tourism to a higher level.

\section{Summary}

At present, although rural tourism is mainly industry operating of individual small farmers, network operation is becoming more and more important and any development and growth are inseparable from information technology. Rather than stay on the sidelines, it is better to take the initiative. The use of information technology in rural tourism has inevitable effect on whether the concept of farmers, or the improvement in actual business performance.

Around the San Wang Yi Ku general plan of “Golden Dragon Project” proposed by National Tourism Administration in 2000, we can publicize the importance of rural tourism information technology through various channels and means, abandon old ideas and conservative ideas, take the initiative try and enhance the tourism information awareness, so that people be aware that information technology has brought us convenience, agility, efficiency, and create a favorable social environment for information construction of rural tourism.

In the seventeenth report, Comrade $\mathrm{Hu}$ Jintao clearly stated: develop modern industrial system, vigorously promote the integration of information and industrialization, and promote the industry to grow stronger. This new development idea is fully applicable to the tourism industry, to achieve the leap and construction of modern tourism, the key lies is to use information technology to enhance tourism industry modernization. In the current form of high-speed development in information network, looking at the development direction of information construction of rural tourism, we can see the strong development momentum of rural tourism, unlimited space of development, and more types of the development, personalized walking itineraries and creative travel products continue to gush. At the same time, information construction and development of rural tourism should not only protect the authenticity of the original cultural environment, but also focus on the protection of the landscape holding, which is also the focus on information construction of rural tourism.

In the situation of today's rapid development of social network information, to increase the information construction of rural tourism is an important way in rural tourism development, an 
inevitable guarantee of rural tourism development. To increase the expansion of rural tourism information pattern, we should also enhance the post-building of rural tourism information to ensure the sustainable development of rural tourism.

\section{Acknowledgement}

This paper is funded by the Human and Social Science Project "A study of ecological protect and development of Nanchang village tourism” of Nanchang Institute of Technology.

\section{References}

[1] Yao M. Rural tourism development exploration under information environment. Rural Economy and Science, 2013, 9.

[2] Lin T, Liang X. Realistic thinking on agricultural information and increasing peasant. Guangxi Agricultural Sciences, 2005(06).

[3] Chen H. Research on development and optimization of tourism information services. Shandong Normal University, 2007. 